\title{
Spatial and temporal variation in the genetic structure of Dascyllus trimaculatus (Pomacentridae) in the Bohol Sea
}

\author{
Ma. Carmen Ablan Lagman*
}

\begin{abstract}
The potential of microsatellite markers to detect the spatial and temporal genetic structure of reef fish populations within a linear distance of $300 \mathrm{~km}$ in the absence of geographic barriers was tested in the Bohol Sea, central Philippines, using the three-spot damselfish Dascyllus trimaculatus. A total of 672 samples from 7 populations in the Bohol Sea were processed to determine temporal and spatial patterns of genetic variability using ten previously developed and tested microsatellite markers. The extent of differentiation was determined based on a variance-based measure of population structure $\mathrm{F}_{\mathrm{ST}}$ and $\mathrm{R}_{\mathrm{ST}}$, and genetic distances $\mathrm{D}_{\mathrm{s}}, \mathrm{D}_{\mathrm{A}}$, and $\mathrm{dm}^{2}$, each of which makes different assumptions on the process of migration, mutation, selection, and genetic drift. Patterns of temporal and spatial variation were consistent among 36 possible pairs of populations. Reef groups are defined as (1) the Mantigue-Dinagat on the northeast edge of the Bohol Sea; (2) the Selinog and Dapitan islands, to the southwest and central Bohol sea populations (3) Apo and (4) Sumilon to the west, and (5) Balicasag group to the northwest. The presence of structure in the absence of geographic barriers suggests the influence of strong surface circulation patterns that differ from the east to the west side of the region. The consistency of a population's genetic signatures over multiple temporal sampling dates implies strong habitat selection for genotypes. Genetic breaks were detected at a distance $4 \mathrm{x}$ greater than the marine protected area's average size, suggesting a minimum linear distance for networking of MPAs should be expanded to this scale.
\end{abstract}

Keywords: Conservation, Hardy-Weinberg equilibrium, marine protected area, microsatellite markers, population genetics, reef fish

\section{Introduction}

Genetic population structure is a powerful means to understand population dynamics and connectivity of potential fisheries and conservation management units. Genes mediate the relationship between an organism and its environment (Cavalli and Heard 2019). Therefore, the population's genetic structure reflects the unique relationship between the species and its environment (Sukumaran and Knowles 2017).

Genetic differentiation has traditionally been challenging to determine in marine species because of the low levels of variation detected in these species (reviewed by Reiss et al. 2009). Genetic structure was formerly thought to be significant only at ocean-wide scales because of the long-distance migration and larval dispersal (Hauser and Ward 1998). To

De La Salle University 2401 Taft Avenue Malate, Manila 1004 Philippines

*Corresponding email: ma.carmen.lagman@dlsu.edu.ph

Date Submitted: 24 June 2020

Date Accepted: 16 January 2021 date, other features and processes, such as barriers to gene flow, natural selection, genetic drift, and habitat preferences, have been increasingly explored as drivers of genetic population structure in marine species (Sanford and Kelly 2011). These later studies indicate that genetic structure does exist, but that it cannot be detected by the genetic marker used (Kelley et al. 2016).

Marine fish, whether migratory and pelagic or habitatassociated and demersal, have widely dispersing larvae and weakly structured adult populations (Planes 2002). Yet, they often present chaotic genetic heterogeneity on small spatial scales. Genetic heterogeneity results from variance in individuals' success in matching the reproductive activity with oceanographic conditions that favor the fertilization of eggs, larval development, and eventual settlement (Hedgecock and Pudovkin 2011). For habitat-associated species, gene flow and eventual population structure may be restricted mainly because of the patchiness of the distribution of environments in which a species may thrive (Blanco Gonzalez et al. 2016). The availability of habitats and habitat heterogeneity may have a more significant influence on genetic structuring in such a group, which will have to settle as adults, rather than the duration of the pelagic phase or the capacities of larvae dispersal 


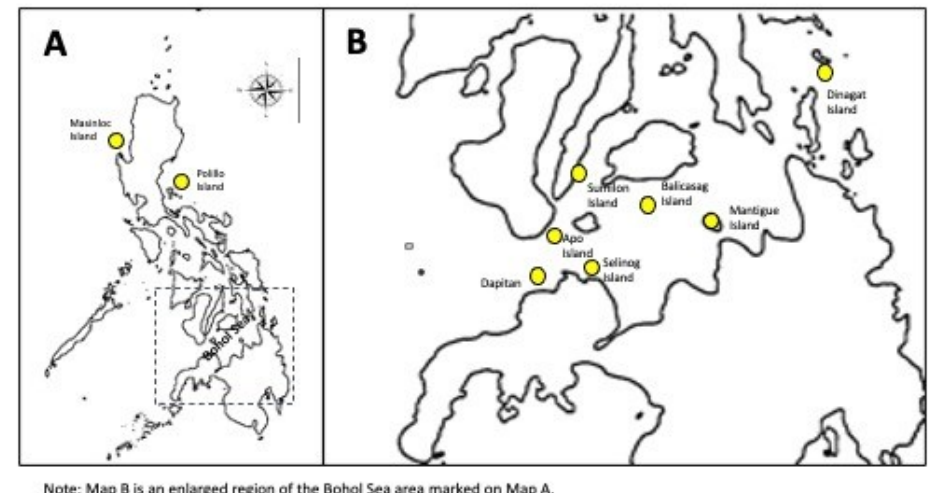

Figure 1. Sampling sites of D. trimaculatus in the Philippines and in the Bohol Sea

(Gardner et al. 2017). The empirical finding of genetic structure in habitat-associated species with relatively low dispersal potential indicates ecological effects may promote genetic variation, as in the case of habitat heterogeneity (Ackiss et al. 2010).

Of the available markers, non-coding, highly polymorphic, and co-dominantly inherited, tandemly repeating microsatellites distributed throughout the genome are most suitable for studies of population structure, pedigree analysis, and research involving populations or closely related species (Ward 2002). Amplification of microsatellites with polymerase chain reaction (PCR) may be highly automated, enabling rapid processing of many samples for genotypes at many loci. Microsatellites can resolve fine-scale population differences because of their codominant nature of inheritance; thus, multiple-locus evaluation of genotype frequencies are accessible via widely-applied data analysis pipelines (Ward et al. 2005). Finally, microsatellite studies require a small amount of tissue from fin clips or blood, allowing for non-invasive sampling (Abdul-Muneer 2014). Average heterozygosity based on microsatellites is high. As many as 66 alleles per locus have been screened in fish (DeWoody and Avise, 2000). These markers can detect the occurrence of low but significant levels of differentiation in populations in the presence of high gene flow and at small spatial scales (Knutsen et al., 2003). As such, microsatellites have the potential to detect genetic structure explained by ecological and evolutionary processes such as sea surface currents, environmental gradients, and geographic isolation (Huyghe and Kochzius 2018).

This study investigates the source and sink dynamics of reef resources using microsatellite markers at the scale of the Bohol Sea (Fig. 1). Will microsatellites resolve patterns of genetic structure that will be relevant to fisheries management at the spatial scale of $300 \mathrm{~km}$ ? The three-spot damselfish,
Dascyllus trimaculatus (Rüppell, 1829), was chosen as a model organism for this study. It is wide-spread, abundant, and is not subject to fishing pressure in the area. Previous genetic studies for this species complex at the scale of the Indo-Pacific region have recorded the strong influence of ecological factors in the diversification of species based on both microsatellite and mtDNA markers (Leray et al. 2010). Therefore, this species was selected to investigate genetic structure across the Bohol Sea, and will was chosen to test this class of marker's ability to resolve genetic structure at this small scale.

\section{Materials and Methods}

\section{The Study Site}

The Bohol Sea covers $29,000 \mathrm{~km}^{2}$, stretching $270 \mathrm{~km}$ from the Sulu Sea to the Pacific Ocean. The islands of Mindanao to the south and east, Negros, Bohol to the north and west surround it. Marine Protected Areas are gaining popularity and support as a fisheries management and biodiversity conservation tool in this area. Over 40 marine protected areas exist on the coastlines of the Bohol Sea. Local communities are responsible for managing these MPAs, with varying support levels from the local government (Indab and Suarez-Aspilla 2004). Seven study sites in the Bohol Sea were chosen from the 40 areas with marine reserves. These sites were selected because they were in shallow seas, between small islands separated from larger, nearby islands by a channel of at least $5 \mathrm{~km}$. Sampling sites were selected adjacent to small islands (Apo Island, Sumilon Island, Balicasag Island, Selinog Island, and Mantigue Island ), where reefs are relatively unaffected by land-based development activities or freshwater input. Samples were collected just outside of the reserves. The sites of sampling are found in Figure 1.

\section{Laboratory Analysis}

Temporal and spatial variability in allele frequencies at ten microsatellite loci of 27-50 thirty individuals of $D$. trimaculatus were determined from populations in Apo Island, Balicasag Island, Sumilon Island, Selinog Island, and Mantigue Island, once every year for the two-year study period. More frequent inter-monsoon sampling was carried out at Apo Island and Balicasag Island. Two other populations from the eastern and the western Philippine boundary islands of Polillio in Quezon and Masinloc in Zambales were also included in the study as out -groups. The numbers of samples per site of the collection are found in Table 1.

Muscle tissue was cut out from below the first dorsal spine of each fish and preserved in 95\% ethanol. Total DNA was extracted from about $100 \mathrm{ug}$ of fish tissue using either the DNA 
Lagman: Variation in the genetic structure of Dascyllus trimaculatus in the Bohol Sea

Table 1. Inventory of samples collected between 2001-2003 by site and monsoon season

\begin{tabular}{|c|c|c|c|c|c|}
\hline Area & Site & No. of individuals & Sample Code & Combined Code & Total \\
\hline & Apo & 43 & AINE2002 & APO & 163 \\
\hline & Island & 44 & AINE2003 & & \\
\hline & & 42 & AISW2001 & & \\
\hline & & 34 & AISW2002 & & \\
\hline Bohol & Sumilon & 38 & SMNE2002 & SUM & 62 \\
\hline Sea & Island & 42 & SMSW2001 & & \\
\hline \multirow[t]{10}{*}{ Samples } & Balicasag & 38 & BLNE2002 & BAL & 154 \\
\hline & Island & 45 & BLNE2003 & & \\
\hline & & 32 & BLSW2001 & & \\
\hline & & 39 & BLSW2002 & & \\
\hline & Selinog & 35 & SWNE2003 & SE & 67 \\
\hline & Island & 32 & SESW2001 & & \\
\hline & Dinagat & 35 & DPNE2003 & DAP & 35 \\
\hline & Mantigue & 27 & MNNE2003 & MAN & 66 \\
\hline & Island & 39 & MNSW2001 & & \\
\hline & Dinagat & 30 & DNNE2003 & DIN & 30 \\
\hline \multicolumn{6}{|l|}{ Non } \\
\hline Bohol Sea & Masinloc & 50 & ZAM1998 & ZAM & 50 \\
\hline Samples & Polillo Islan & 44 & QUE1998 & QUE & 44 \\
\hline
\end{tabular}

Tech extraction kit (Biotech, Thailand) or VIOGEN plant genomic DNA extraction kit (Viogene, Taiwan) according to the manufacturer's specifications. Genetic variation was assayed at each of 10 independent microsatellite loci previously isolated and characterized for Dascyllus trimaculatus (Ablan 2005). Eighteen populations with at least 30 fish samples per site were analyzed for ten microsatellite markers altogether.

PCR amplifications were performed under the following general conditions: $3 \mathrm{~min}$ at $94^{\circ} \mathrm{C}$, then $30-40$ cycles of $30 \mathrm{~s}$ at $94^{\circ} \mathrm{C}, 30 \mathrm{~s}$ at the specific annealing temperatures $\left(54-68^{\circ} \mathrm{C}\right.$ for the ten primers), and $1 \mathrm{~min}$ at $72^{\circ} \mathrm{C}$ and a final extension step of $5 \mathrm{~min}$ at $72^{\circ} \mathrm{C}$. PCR was carried out in $10 \mathrm{ul}$ reaction volumes containing $20 \mathrm{ng}$ of template DNA, $1.5-2.5 \mathrm{mM} \mathrm{MgCl}$ (Sigma, USA), $0.2 \mathrm{mM}$ of each dNTP, 0.25 pmoles of forward and reverse primers, and 0.25 units of Taq polymerase (Fermentas, USA or Sigma, USA). Temperature requirements for PCR amplification are found in Table 2. Microsatellite DNA fragments were resolved through a GelScan 2000 automatic mini-sequencer (Corbett Research) using primers that were florescent labeled with HEX. Alleles were designated according to the PCR fragment's sizes relative to the migration of know TAMARA marked size standards (ABI Gene Scan 500). Samples that were difficult to score were reanalyzed using new PCR products. One-D Scan (Scanalytics, USA) was used to read gels and determine genotypes to a minimize size bias.

\section{Data Analysis}

Allele richness, the observed proportion of heterozygotes, within-sample gene diversity, and overall gene diversity were calculated for each locus . Departures from Hardy-Weinberg equilibrium were assessed by a Markov chain method to estimate, without bias, exact $\mathrm{p}$-values (Guo and Thompson 1992) using GENEPOP 3.4 (Raymond and Rousset 1995; http:// www.cefe.cnrs-mop.fr). Significance values were adjusted for multiple simultaneous tests using the Bonferroni correction.

The Student's t-test was used to test for significant differences in mean expected heterozygosity $\left(\mathrm{H}_{\mathrm{e}}\right)$ between repeat samples from the same site. Differences in the distribution of alleles across repeat samples were determined by calculating an unbiased estimate of the p-value based on Fisher's exact test at each locus described by Raymond and Rousset (1995). Pairwise $F_{S T}$ and $R_{S T}$ across all loci among repeat samples were likewise calculated to infer differentiation among repeat samples, and these compared to values obtained for all populations. Where values were significantly different across repeat samples, they were not pooled; otherwise, repeat samples were pooled.

The estimated $\mathrm{F}_{\mathrm{ST}}$ was calculated using FSTAT (Goudet 1995). RSTCALC was used to calculate $R_{S T}$ and related statistics (Goodman 1997) and departures from zero of all measures of differentiation permutation tests. The two estimates 
Lagman: Variation in the genetic structure of Dascyllus trimaculatus in the Bohol Sea

Table 2. PCR conditions for amplification of 10 microsatellites of Dascyllus trimaculatus

\begin{tabular}{|c|c|c|c|c|c|c|c|c|}
\hline \multicolumn{9}{|c|}{ PCR Conditions } \\
\hline Primer & $\begin{array}{c}\text { DNA template } \\
\text { (ng) }\end{array}$ & Buffer & $\begin{array}{l}\text { DNTPs } \\
(\mathrm{mM})\end{array}$ & $\begin{array}{r}\mathrm{MgCl}_{2} \\
(\mathrm{mM})\end{array}$ & $\begin{array}{l}\text { Primer } \\
(\mathrm{pM})\end{array}$ & $\begin{array}{c}\text { Taq } \\
\text { (units) }\end{array}$ & $\begin{array}{l}\text { Annealing Temp } \\
(\mathrm{oC})\end{array}$ & PCR cycles \\
\hline Dt28 & 20 & $1 x$ & 0.1 & 1.5 & 0.25 & 0.5 & 55 & 40 \\
\hline Dt16 & 20 & $1 x$ & 0.1 & 1.5 & 0.25 & 0.5 & 55 & 40 \\
\hline Dt39 & 20 & $1 x$ & 0.1 & 1.5 & 0.25 & 0.5 & 55 & 40 \\
\hline Dt311 & 20 & $1 x$ & 0.1 & 1.5 & 0.25 & 0.5 & 55 & 40 \\
\hline Dt38 & 20 & $1 \mathrm{x}$ & 0.1 & 1.5 & 0.25 & 0.5 & 55 & 40 \\
\hline Dt55 & 20 & $1 \mathrm{x}$ & 0.1 & 1.5 & 0.25 & 0.5 & 65 & 35 \\
\hline Dt510 & 20 & $1 x$ & 0.1 & 1.5 & 0.25 & 0.5 & 68 & 35 \\
\hline Dt13 & 20 & $1 \mathrm{x}$ & 0.1 & 1.5 & 0.25 & 0.5 & 55 & 35 \\
\hline Dt51 & 20 & $1 x$ & 0.1 & 2.5 & 0.25 & 0.5 & 60 & 35 \\
\hline Dt17 & 20 & $1 x$ & 0.1 & 1.5 & 0.25 & 0.5 & 54 & 40 \\
\hline
\end{tabular}

were used to determine if the allele size assumption is of consequence at this fine scale.

Both pairwise $\mathrm{F}_{\mathrm{ST}}$ (the proportion of the total genetic variation contained within a subpopulation) or $\mathrm{R}_{\mathrm{ST}}$ (an $\mathrm{F}_{\mathrm{ST}}$ equivalent, assuming a stepwise mutation model) matrices were used as the geographic distance matrix for Mantel tests. A geographic distance matrix was created from linear distances measured between sampling points from a 1:20,000 map of the southern Philippines. Correlation between the symmetrical geographic and genetic matrices was tested using the Mantel permutation procedure (Mantel 1967). The pairwise $\mathrm{F}_{\mathrm{ST}}$ or $\mathrm{R}_{\mathrm{ST}}$ statistics served as the geographic matrix input into a Mantel permutation procedure within the FSTAT program. A significant correlation between these two matrices indicates the relative importance of gene flow over genetic drift.

For this part of the study, three distance estimates $\mathrm{D}_{\mathrm{S}}(\mathrm{Nei}$, 1972, 1978), $\mathrm{D}_{\mathrm{A}}$ modified from the original Cavalli-Sforza chord distance (Nei et al. 1983) and $\mathrm{dm}^{2}$ (Goldstein et al. 1995) were calculated. The program DISAPAN generated $\mathrm{D}_{\mathrm{S}}$ and $\mathrm{D}_{\mathrm{A}}$ while RST CALC generated $\mathrm{dm}^{2}$ values. Neighbor-joining trees for each of these genetic distance matrixes were drawn to present the extent to which populations diverge visually. Bootstrap tests (Felsenstein 1985) were performed for these trees to determine the most appropriate configuration.

\section{Results and Discussion}

\section{Conformity to Hardy-Weinberg Equilibrium}

Levels of genetic variability calculated for each of the nine sites of pooled samples were very similar across populations, whether they were within or outside the Bohol Sea. Expected heterozygosity $\left(\mathrm{H}_{\mathrm{e}}\right)$ for populations ranged from $\mathrm{H}_{\mathrm{e}}=$ 0.596 for Dinagat on the eastern, Pacific seaboard side of the Philippines, to $\mathrm{H}_{\mathrm{e}}=0.691$ Zambales (Fig. 1), on the side of the West Philippine Sea. (Table 3). Twenty-one of the ninety singlelocus $\mathrm{H}_{\mathrm{e}}$ values were significantly different from HardyWeinberg predictions. Only twelve of these remained significantly departing from Hardy-Weinberg expections when adjusted for table-wide significance by a sequential Bonferroni procedure. Based on the comparisons, departures were found at loci Dt 311, Dt 38, and Dt 13 and these loci were excluded from further analysis. The remaining seven loci were considered to exhibit close conformity with outcrossing expectations of Hardy

Table 3. Heterozygosity (Ho, $\mathrm{Hs}$ and $\mathrm{Ht}$ ) from 10 microsatellite markers

\begin{tabular}{cccc}
\hline Locus & Ho & Hs & Ht \\
\hline Dt311 & 0.706 & 0.819 & 0.867 \\
Dt28 & 0.715 & 0.727 & 0.765 \\
Dt39 & 0.454 & 0.461 & 0.490 \\
Dt38 & 0.830 & 0.806 & 0.858 \\
Dt16 & 0.364 & 0.333 & 0.336 \\
Dt510 & 0.657 & 0.739 & 0.795 \\
Dt55 & 0.754 & 0.775 & 0.825 \\
Dt51 & 0.457 & 0.490 & 0.599 \\
Dt13 & 0.550 & 0.654 & 0.723 \\
Dt17 & 0.762 & 0.786 & 0.820 \\
Overall & 0.625 & 0.659 & 0.708 \\
\hline
\end{tabular}


Table 4. Conformity of allele frequencies from 10 microsatellite to Hardy-Weinberg Equilibrium

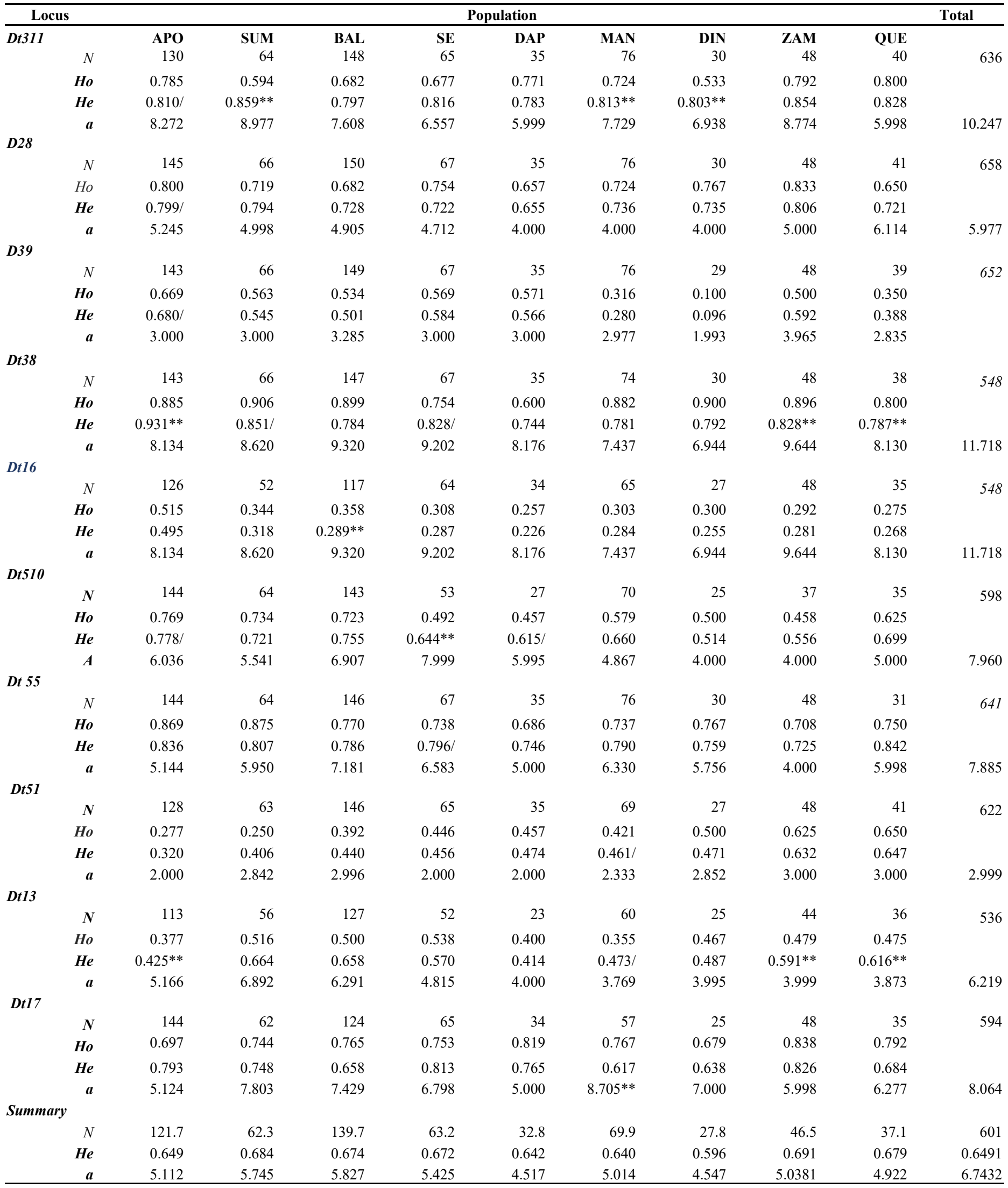

** $\mathrm{P}<0.01$ - significant departure from Hardy-Weinberg Equilibrium 
-Weinberg Equilibrium and were used in downstream analyses of structure among the 9 populations. (Table 4).

\section{Temporal Variability and Structure}

Genetic variability $\left(\mathrm{H}_{\mathrm{e}}\right)$ for D. trimaculatus between temporal samples from the same site were generally stable over time. Significant differences were detected in only 34 temporal comparisons from out of 15 comparisons based on either Student's t-test, exact probability tests, and pairwise $\mathrm{F}_{\mathrm{ST}}$ probabilities (Table 5). The significant differences were most observed among repeat samples within the Apo Island and Balicasag Island sites. At these sampling sites, repeated sampling was more intensive, and temporal comparisons were more frequent, inherently increasing the likelihood of finding differences. These results were the basis for the decision to pool temporally-repeated samples from a given site, for subsequent analyses.

The stability in temporal genetic variation contradicts predictions of large variances in individual genotypes' reproductive success, as predicted by sweepstakes reproduction hypothesis (Hedgecock and Pudovkin 2011). This hypothesis predicts a few individuals' reproductive success across sampling periods, which would otherwise reflect as sharp genetic discontinuities and reduced $\mathrm{H}_{\mathrm{e}}$. D. trimaculatus is a sedentary species, less likely to disperse over large distances compared to other reef fish species and are site-attached as adults. This species lays demersal eggs, unlike the others, which spawn gametes into the water column (Bernardi et al. 2002). They have eggs that adhere to the substrate before hatching into competent larvae, thus eliminating a phase of passive transport of eggs in the water column (Breder and Rosen 1966) and perhaps reduce uncertainties, which favor the reproductive success of few individuals.

The duration of the pelagic larval stage in D. trimaculatus is 20-25 days and the species' competent swimming larvae have the potential to disperse far from their natal reef (Robitzch et al. 2015). However , D. trimaculatus is likely to be among the species predicted to have dispersal ranges at the lower end of the typical 10-100 km dispersal distances of reef fish (Jones et al. 2009). At these scales, temporal stability in genetic variation across sites may also be a result of habitat selection (Martinez et al. 2018).

The Bohol Sea is dominated by a year-round downstream current, which flows from the Pacific Ocean to the Sulu Sea (Cabrera et al. 2011). This constant current is expected to transport propagules from the eastern, to the western end of the Bohol Sea. Theoretically, reefs in the Bohol Sea are 'sinks' of a gamut of genotypes originating from the Pacific; thus, the genetic variability of incoming larvae should be less of a restriction than would the availability of suitable habitats. Differences in genetic variation have been shown to reflect differences and gradients in habitats (Nanninga et al. 2013) and stability in temporal variation may reflect habitat selection. Selective survival and settling in of juveniles with very similar genotypes are rather than a limitation in larval dispersal or genetic variability of arriving juveniles.

A third possible explanation for temporal stability in genetic variability might be that, across sites, naturally low genetic variability (as detected by the microsatellite markers) in the Bohol Sea in populations of D. trimaculatus is natural, or

Table 5. Temporal comparison of allele frequencies from the same site

\begin{tabular}{|c|c|c|c|c|}
\hline Site & Samples compared & t-test for $H_{e}$ & Exact Probabilities & Pairwise $\mathbf{F}_{\text {st }}$ \\
\hline \multicolumn{3}{|c|}{$(\mathrm{P}<0.05)$} & $(\mathrm{P}<0.00028)$ & $(\mathrm{P}<0.000372)$ \\
\hline \multirow[t]{6}{*}{ Apo } & AINE02xAINE03 & $\mathrm{P}=0.783$ & $\mathrm{P}=0.00004^{*}$ & $\mathrm{P}=0.00301$ \\
\hline & AINE02xAISW01 & $\mathrm{P}=0.029^{*}$ & $\mathrm{P}=0.00157$ & $\mathrm{P}=0.15065$ \\
\hline & AINE02xAISW02 & $\mathrm{P}=0.805$ & $\mathrm{P}=0.00002 *$ & $\mathrm{P}=0.00373$ \\
\hline & AINE03xAISW01 & $\mathrm{P}=0.068$ & $\mathrm{P}=0.00056$ & $\mathrm{P}=0.00026^{*}$ \\
\hline & AINE03xAISW02 & $\mathrm{P}=0.010^{*}$ & $\mathrm{P}=0.00044$ & $\mathrm{P}=0.00065$ \\
\hline & AISW01xAISW02 & $\mathrm{P}=0.596$ & $\mathrm{P}=0.68696$ & $\mathrm{P}=0.24673$ \\
\hline Sumilon & SMNE03XSMSW01 & $\mathrm{P}=0.000^{*}$ & $\mathrm{P}=0.0753$ & $\mathrm{P}=0.00130$ \\
\hline \multirow[t]{6}{*}{ Balicasag } & BLNE02XBLNE03 & $\mathrm{P}=0.682$ & $\mathrm{P}=0.05194$ & $\mathrm{P}=0.00314$ \\
\hline & BLNE02XBLSW01 & $\mathrm{P}=0.075$ & $\mathrm{P}=0.00030$ & $\mathrm{P}=0.09804$ \\
\hline & BLNE02XBLSW02 & $\mathrm{P}=0.733$ & $\mathrm{P}=0.00000 *$ & $\mathrm{P}=0.00007^{*}$ \\
\hline & BLNE03XBLSW01 & $\mathrm{P}=0.132$ & $\mathrm{P}=0.12540$ & $\mathrm{P}=0.50725$ \\
\hline & BLNE03XBLSW02 & $\mathrm{P}=0.927$ & $\mathrm{P}=0.00116$ & $\mathrm{P}=0.00007 *$ \\
\hline & BLSW01XBLSW02 & $\mathrm{P}=0.165$ & $\mathrm{P}=0.00000^{*}$ & $\mathrm{P}=0.00227$ \\
\hline Selinog & SWNE03 X SWSW01 & $\mathrm{P}=0.094$ & $\mathrm{P}=0.00325$ & $\mathrm{P}=0.00052$ \\
\hline Mantigue & MNNE03xMNSW01 & $\mathrm{P}=0.927$ & $\mathrm{P}=0.05257$ & $\mathrm{P}=0.19320$ \\
\hline
\end{tabular}


that habitats sampled are relatively homogenous. The sites chosen for the study are all adjacent to small islands (Apo Island, Sumilon Island, Balicasag Island, Selinog Island, and Mantigue Island ) where reefs are relatively unaffected by landbased development activities or freshwater input; in this sense study sites can be viewed as relatively homogeneous. However, because characterizing genetic variation and spatial structure across the Bohol Sea were objectives of this study, future ecological surveys of habitat structure will be necessary to directly assess environmental homogeneity.

\section{Genetic Variation and Spatial Structure}

Given the primary objective of this study, data from repeat samples were pooled for analyses of spatial differentiation. Fisher's Exact tests for population differentiation detected significant heterogeneity levels $(\mathrm{P}<<0.001)$ in 34 of the 36 possible population pairs. The two exceptions were for the Mantigue-Dinagat and Selinog-Dipolog pairs (Table 6). V alues of $\mathrm{F}_{\mathrm{ST}}=0.0763$ and $\mathrm{R}_{\mathrm{ST}}=0.0737$ suggest the occurrence of population structure among the nine populations in the Bohol Sea. Both $\mathrm{F}_{\mathrm{ST}}$ and $\mathrm{R}_{\mathrm{ST}}$ remained high $\left(\mathrm{F}_{\mathrm{ST}}=0.0733\right.$ and $\mathrm{R}_{\mathrm{ST}}=$ 0.0728), even when out-group populations from Quezon and Zambales were not included in analyses, suggesting that genetic differences among populations in reefs within the Bohol Sea may be as high as among populations within the Bohol Sea versus those on peripheral northeast and northwest boundaries of the Philippines. A dendrogram of genetic relationships, based on $\mathrm{R}_{\mathrm{ST}}$ (Fig. 2), depicts distances on a scale comparable to allozyme variation across the entire West Philippine Sea (Ablan 2005). Values of Fst at this order of magnitude have been observed for Amphiprion clarkii (Bennett, 1830) from southern Japan to the Bonin Islands Amphiprion melanopus Bleeker, 1852, Chromis atripectoralis Welander \& Schutlz, 1951, Pomacentrus moluccensis Bleeker, 1853 and Stegastes nigricans (Lacepède, 1802) at a distance from Cairns and Swain reef, and Chromis cyanea (Poey, 1860) along the Florida Keys (reviewed by Planes 2002). Microsatellites do not necessarily detect higher $\mathrm{F}_{\mathrm{ST}}$ values over other genetic markers, but they can detect genetic structuring amidst gene flow (Hauser and Ward 1998). For coral reef fish, variability in microsatellites increases one's ability to detect population structure, and thus, increases estimates of differentiation among populations.

Genetic distance $D_{S}, D_{A}$, and $\mathrm{dm}^{2}$, each of which has distinct properties, were calculated from the data (Table 7). Whereas $D_{S}$ is sensitive to divergence to time, $D_{A}$ will be more affected by effective population size, and $\mathrm{dm}^{2}$ is primarily related to mutation rates (Kalinowski 2002). $D_{A}$ values were consistently higher than either $\mathrm{D}_{\mathrm{S}}$ or $\mathrm{dm}^{2}$, although these metrics did not differ much.

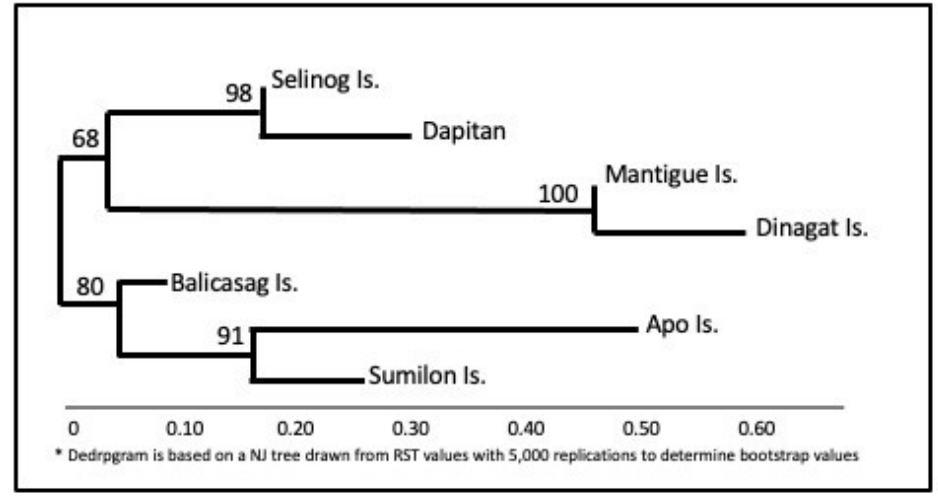

Figure 2. Neighbor-joining trees drawn from genetic distance $\mathrm{dm}^{2}$ for D. trimaculatus

The farthest distance between two points within the Bohol Sea was $303.2 \mathrm{~km}$, and corresponds to the distance between Dinagat and Dapitan islands. Likewise, genetic differentiation between these two populations was the highest observed in this study. The shortest distance between sites measured directly from a map was $28.2 \mathrm{~km}$, and this was between Selinog Island and Dapitan on the west side of the Bohol Sea. No differentiation was detected between these two populations. Genetic breaks were detected at scales of (1) $37.2 \mathrm{~km}$, the linear distance between Apo and Selinog-Dapitan Islands, (2) $41.3 \mathrm{~km}$, the linear between Apo Island and Sumilon Island, and (3) 66.3 $\mathrm{km}$, the linear distance between Apo Island and Balicasag Island. These linear distances are in excess of 10 times greater than the average linear dimension of MPAs in this region.

In contrast to the genetic structure observed on the west side of the Bohol Sea, the islands of Mantigue and Dinagat to the east and central areas, were highly connected at a greater distance of over $120 \mathrm{~km}$, and this is three times the distance wherein genetic breaks are observed on the west side of the Bohol Sea. These data provide insight into the possible shortest larval dispersal distance of a reef fish within the Bohol Sea, and show that adjacent populations separated by $40 \mathrm{~km}$ may not be connected in species of fish with low dispersal potential. On the east side of the Bohol Sea, populations that are further apart were similarly connected. Larval dispersal range and connectivity must be coupled with knowledge of representation of biodiversity for effective design of marine protected area networks (Almany et al. 2009)

\section{Correlation Between Geographic and Genetic Distance}

Only $55.7 \%$ variation in the genetic differences was explained by variation in geographic distances based on Mantel's permutation tests (see Figure 3, indicating that populations in the Bohol Sea do not conform to a stepping-stone isolation-by-distance [IBD] model [Kimura and Weiss 1964]). 
Table 6. Pairwise Fst and Rst values for combined data across nine sites evaluated

\begin{tabular}{|c|c|c|c|c|c|c|c|c|c|}
\hline$\underline{F}_{s t}$ & APO & SUM & BAL & SE & DAP & MAN & DIN & ZAM & QUE \\
\hline$\overline{\mathrm{APO}}$ & & ** & ** & $* *$ & ** & $* *$ & ** & $* *$ & $* *$ \\
\hline SUM & 0.0285 & & $* *$ & $* *$ & $* *$ & $* *$ & $* *$ & $* *$ & $* *$ \\
\hline BAL & 0.0623 & 0.0135 & & $* *$ & $* *$ & $* *$ & $* *$ & $* *$ & $* *$ \\
\hline SE & 0.1095 & 0.0764 & 0.0678 & & NS & $* *$ & $* *$ & $* *$ & $* *$ \\
\hline DAP & 0.1381 & 0.0919 & 0.0789 & 0.0058 & & $* *$ & $* *$ & $* *$ & $* *$ \\
\hline MAN & 0.1317 & 0.089 & 0.0706 & 0.0493 & 0.0579 & & NS & $* *$ & $* *$ \\
\hline DIN & 0.1491 & 0.1025 & 0.0847 & 0.0611 & 0.0709 & -0.0002 & & $* *$ & $* *$ \\
\hline ZAM & 0.1391 & 0.0944 & 0.0937 & 0.0519 & 0.0643 & 0.0888 & 0.0996 & & $* *$ \\
\hline QUE & 0.1083 & 0.053 & 0.0399 & 0.0570 & 0.0785 & 0.0628 & 0.0788 & 0.0663 & \\
\hline$\underline{\boldsymbol{R}_{s t}}$ & APO & SUM & BAL & SE & DAP & MAN & DIN & ZAM & QUE \\
\hline APO & & $* *$ & ** & $* *$ & ** & $* *$ & ** & $* *$ & ** \\
\hline SUM & 0.0258 & & $* *$ & $* *$ & $* *$ & $* *$ & $* *$ & $* *$ & $* *$ \\
\hline BAL & 0.0427 & 0.0073 & & $* *$ & $* *$ & $* *$ & $* *$ & $* *$ & $* *$ \\
\hline SE & 0.0752 & 0.0638 & 0.0726 & & NS & $* *$ & $* *$ & $* *$ & $* *$ \\
\hline DAP & 0.0645 & 0.0478 & 0.0641 & -0.0052 & & $* *$ & $* *$ & $* *$ & $* *$ \\
\hline MAN & 0.1195 & 0.1262 & 0.1146 & 0.0805 & 0.1195 & & NS & $* *$ & $* *$ \\
\hline DIN & 0.1177 & 0.1296 & 0.1281 & 0.0885 & 0.1273 & -0.0072 & & $* *$ & $* *$ \\
\hline ZAM & 0.0946 & 0.1033 & 0.1166 & 0.0050 & 0.0210 & 0.0583 & 0.0580 & & $* *$ \\
\hline QUE & 0.0930 & 0.0725 & 0.0435 & 0.0547 & 0.0704 & 0.0614 & 0.0784 & 0.0699 & \\
\hline
\end{tabular}

** $\mathrm{P}<0.01$ - significant departure from Hardy-Weinberg Equilibrium

Table 7. Pairwise genetic distances from $\mathrm{D}_{\mathrm{S}}, \mathrm{D}_{\mathrm{A}}$ and $\mathrm{dm}^{2}$

\begin{tabular}{|c|c|c|c|c|c|c|c|c|}
\hline$\underline{\mathbf{D}_{\mathrm{S}}}$ & APO & SUM & BAL & SE & DAP & MAN & BIN & ZAM \\
\hline SUM & 0.1348 & & & & & & & \\
\hline BAL & 0.1731 & 0.0637 & & & & & & \\
\hline $\mathrm{SE}$ & 0.1728 & 0.1320 & 0.1068 & & & & & \\
\hline DAP & 0.2583 & 0.1657 & 0.1284 & 0.0377 & & & & \\
\hline MAN & 0.3029 & 0.2539 & 0.1584 & 0.1858 & 0.2106 & & & \\
\hline $\mathrm{BIN}$ & 0.3537 & 0.3005 & 0.2028 & 0.2322 & 0.2441 & 0.0316 & & \\
\hline ZAM & 0.3149 & 0.2379 & 0.1933 & 0.0833 & 0.0801 & 0.2196 & 0.2527 & \\
\hline QUE & 0.2964 & 0.1901 & 0.1261 & 0.1455 & 0.1718 & 0.1884 & 0.2402 & 0.1838 \\
\hline$\underline{\mathbf{D}_{\mathrm{A}}}$ & APO & SUM & BAL & SE & DAP & MAN & BIN & ZAM \\
\hline SUM & 0.1547 & & & & & & & \\
\hline BAL & 0.2356 & 0.0542 & & & & & & \\
\hline SE & 0.2371 & 0.1293 & 0.1513 & & & & & \\
\hline DAP & 0.3287 & 0.1661 & 0.1695 & 0.0146 & & & & \\
\hline MAN & 0.3723 & 0.3912 & 0.2955 & 0.3214 & 0.3316 & & & \\
\hline BIN & 0.3327 & 0.3418 & 0.3359 & 0.3672 & 0.3712 & 0.0030 & & \\
\hline ZAM & 0.3557 & 0.2550 & 0.2377 & 0.0558 & 0.0861 & 0.3927 & 0.3341 & \\
\hline QUE & 0.3210 & 0.1364 & 0.0977 & 0.1259 & 0.1705 & 0.2439 & 0.2941 & 0.1823 \\
\hline $\mathrm{dm}^{2}$ & APO & SUM & BAL & SE & DAP & MAN & BIN & ZAM \\
\hline SUM & 0.1890 & & & & & & & \\
\hline BAL & 0.1391 & 0.0111 & & & & & & \\
\hline SE & 0.0836 & 0.2170 & 0.1900 & & & & & \\
\hline DAP & 0.0907 & 0.1291 & 0.1213 & 0.0231 & & & & \\
\hline MAN & 0.1883 & 0.3242 & 0.3086 & 0.1956 & 0.2333 & & & \\
\hline $\mathrm{BIN}$ & 0.2455 & 0.3751 & 0.3500 & 0.2392 & 0.2789 & 0.0191 & & \\
\hline ZAM & 0.1792 & 0.3548 & 0.3091 & 0.0378 & 0.1055 & 0.2423 & 0.2772 & \\
\hline QUE & 0.1261 & 0.2178 & 0.0786 & 0.1255 & 0.1144 & 0.1816 & 0.2205 & 0.2076 \\
\hline
\end{tabular}




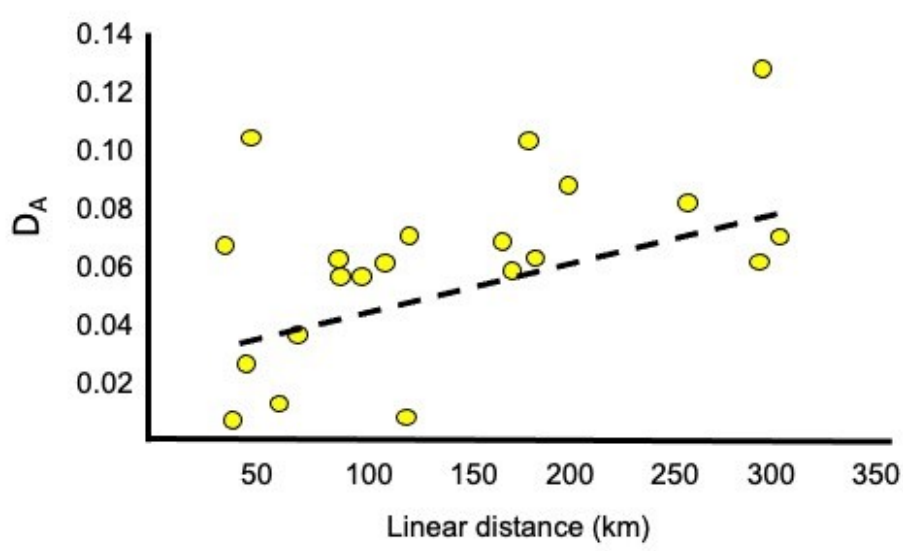

Figure 3. Mantel test for correlation between geographic and genetic distances for D. trimaculatus $\left(\mathrm{r}^{2}=0.557 ; \mathrm{p}<0.01\right)$

Conformation to the IBD model was expected, due to the finding of contrasting patterns of population structure on the Bohol Sea west and east-central regions. Results show, however, that processes other than expansion, via a stepping stone model of isolation by distance, occurs among the damselfish populations. If translated to the general function of interaction among more sessile organisms on reefs, this pattern may imply a need to design local MPA networks of protection around the scales of 30-40 $\mathrm{km}$ distances, given that genetic population breaks naturally occur at these distances.

Surface circulation patterns and geomorphology of reefs suggest the occurrence of a strong consistent and seasonally persistent Bohol Jet current, flowing from the Pacific seaboard. as the Pacific Countercurrent enters into the Philippine archipelago through the channels just south and north of the Dinagat islands, possibly transporting propagules into the Bohol Sea, and which finally may reach reefs $120 \mathrm{~km}$ away, such as those in Mantigue Island. Micro-circulation patterns along various island reefs, as the current flows toward the western margin of the Bohol Sea, may lead to entrainments, creating the pattern of genetic structuring observed in D. trimaculatus. High variation in abundance and diversity of coral community assemblages occur among reefs separated by short distances (Aileen Maypa, pers. comm.), and gradients in assemblage of fish abundance across the Bohol sea have also been observed (Abesamis et al. 2006). The community assemblage data reported by Abesamis et al. (2006) suggest that habitat selection of genotypes may be occurring at these tiny scales, as reflected in geographically-structured microsatellite variation detected here.

\section{Conclusions and Recommendations}

This study demonstrates the ability of moderately variable microsatellite markers to detect population structure and infer connectivity among populations, in a demersal habitatdependent coral reef fish (D. trimaculatus) at scales of $300 \mathrm{~km}$. The patterns were the same using variation-based differentiation statistics $\left(\mathrm{F}_{\mathrm{ST}}\right.$ and $\left.\mathrm{R}_{\mathrm{ST}}\right)$ or distance measures $\left(\mathrm{D}_{\mathrm{S}}, \mathrm{D}_{\mathrm{A}}\right.$, and $\left.\mathrm{dm}^{2}\right)$, although the latter focus on different processes of differentiation - divergence through times, effective population sizes, or mutation rates. A second major outcome of this study provides an example of stability in temporal genetic variation in populations that inhabit reef environments, contrary to the expected occurrence of genetic discontinuities and low $\mathrm{H}_{\mathrm{e}}$ values, predicted from a sweepstakes reproduction hypothesis, and possibly because recruits to a reef are from the same gene pool, or, that genetic structure reflects the structure of habitats. The latter plays a significant role in determining the type of individuals that settle on a reef. Finally, genetic differences among Bohol Sea sites are not necessarily less than differences between a site in the Bohol Sea versus one outside the Bohol Sea (on the outer periphery of the archipelago), indicating a high tendency for $D$. trimaculatus to differentiate, presumably via genetic drift. In the Bohol Sea, gene flow among populations is a necessary process that balances genetic drift (in the absence of physical barriers), and the presence of a simple, unidirectional downstream current throughout the year. Genetic drift promotes structuring, while gene flow homogenizes the gene pool. This relationship between drift and migration would be an exciting topic for further studies.

The occurrence of genetic structure was exploited in this study to determine an initial suggestion for a linear scale for developing networks of MPAs in the Bohol Sea. Three general groups of populations were established. These were a (1) Northwestern group, which included Apo, Sumilon, and Balicasag; the (2) Southwestern highly-connected reefs of Selinog and Dapitan; and (3) Central and eastern Mantigue and Dinagat sites. The shortest distances at which genetic breaks occur were four times the linear distance of a marine reserve, suggesting the scale for the size of marine reserves should be expanded to about this scale. It is noted that more MPAs are found in the downstream area of the Bohol Sea and fewer toward the inlet from the Pacific. Efforts to establish additional reserves should be prioritized in areas upstream, given biodiversity importance. This study's voluminous data should be further analyzed using non-model based exploratory data analysis, and pattern detection software to test hypotheses of spatial and temporal structure in D. trimaculatus populations and to determine whether habitat selection is an important driver 
of genetic diversity in Bohol Sea damselfish.

\section{Acknowledgements}

The author is greatly indebted to Dr. Angel C. Alcala and his team of researchers and research managers at the Silliman University Angelo King Center for Research and Environment Management in Dumaguete for the privilege to be involved and to learn from his initiatives with MPAs in the Bohol Sea, from which this study was one of the results.

\section{Literature Cited}

Abdul-Muneer, P.M., 2014. Application of microsatellite markers in conservation genetics and fisheries management: recent advances in population structure analysis and conservation strategies. Genetics Research International, 2014: ID 691759. doi.org: $10.1155 / 2014 / 691759$.

Abesamis, R.A., G.R. Russ \& A.C. Alcala, 2006. Gradient abundance of fish across no-take marine reserve boundaries: evidence from Philippine coral reefs. Aquatic Conservation, 16(4): 349-371.

Ablan, M.C.A., 2005. Chapter 3: Isolation and characterization of microsatellite loci from the three-spot damselfish $D$. trimaculatus and the yellow-bellied fusilier Caesio cuning. Ph.D. Dissertation manuscript, University of the Philippines Diliman https://ds.mainlib.upd.edu.ph/Record/ UPD-00000486058\#details

Ablan, M.C.A., 2006. Microsatellite loci for studies on population differentiation and connectivity of the redbellied yellow tail fusilier, Caesio cuning (Caesionidae). Molecular Ecology Notes, 6(1): 170-172.

Ablan, M.C.A., J.W. McManus, C.A. Chen, J. Bell, A.S. Cabanban, V.S. Tuan \& I.W. Arthanana, 2002. Meso-scale transboundary units for the management of coral reefs in the South China Sea area. NAGA, 25(3/4): 4-9.

Ackiss, A., S. Perdede, E.D. Crandall, M.C.A. Ablan-Lagman, Ambryanto, N. Romena, P.H. Barber \& K.E. Carpenter, 2010. Pronounced genetic structure in a highly mobile coral reef fish, Caesio cuning, in the Coral Triangle. Marine Ecology Progress Series, 480: 185-197.

Alcala, A., 2001. Marine Reserves in the Philippines: Historical Development Effects and Influence on Marine Conservation Policy. Makati City: The Bookmark. 178 pp.

Almany, G.R., S.R. Connelly, D.D. Heath, J.D. Hogan, G.P. Jones, L.J. McCook \& M. Mills, 2009. Connectivity, biodiversity, conservation and the design of marine reserve networks for coral reefs. Coral Reefs, 28(2): 339-351.
Bernardi G., S.J. Holbrook, R.J. Schmitt, N.L. Crane \& E. DeMartini, 2002. Species boundaries, populations and colour morphs in the three spot damsel (Dascyllus trimaculatus) species complex. Proceedings of the Royal Society of London B: Biological Sciences: 269(1419): 599605.

Berthier, P., M. A. Beumont, J.M. Cornuet \& G. Luikart, 2002. Likelihood-based estimation of the effective population size using temporal changes in allele frequencies: a genealogical approach. Genetics, 160: 741-751.

Blanco Gonzalez, E., H. Knutsen \& P.E. Jorde, 2016. Habitat discontinuities separate genetically divergent populations of a rocky shore marine fish. PLOS ONE 11(10): e0163052. 2016 doi: 10.1371/journal.pone.0163052.

Breder, C.M. \& D.E. Rosen, 1966. Modes of Reproduction in Fishes. TFH Publications, Neptune City, New Jersey. 941 p. Cabrera, O.C., C.L. Villanoy, L.T. David \& A.L. Gordon, 2011. Barrier layer control of entrainment and upwelling in the Bohol Sea, Philippines. Oceanography 24(1): 130-141.

Canales-Aguirre, C.B., S. Fernanda-Fuentes, R. Galleguillos \& C.E. Hernandez, 2016. Genetic structure in a small pelagic fish coincides with a marine protected area: seascape genetics in Patagonian fjords. PLOS ONE 11(6): e016067. 2016 doi: 10.1371/journal.pone. 016067

Cavalli, G. \& E. Heard, 2019. Advances in epigenetics link to the environment and disease. Nature 571: 489-499

Chakraborty, R. \& L. Jin, 1993. A unified approach to study hypervariable polymorphism: statistical considerations of determining relatedness and population distances. In: Pena S.D.J.,

R. Chakraborty, J.T. Epplen, \& A.J. Jeffreys, (ed.), DNA Fingerprinting: State of the Science. Birkhauser Verlag, Basel, Switzerland. pp. 153-175.

Cornuet, J., S. Piry, G. Luikart, A. Estoup, A., \& M. Solignac., 1999. New methods employing multilocus genotypes to select or exclude populations as origins of individuals. Genetics. 153:1989-2000.

Cutter, A.D., 2019. A Primer for Molecular Population Genetics. Oxford University Press. Oxford, UK. 243 pp.

DeWoody, J.A. \& J.C. Avise, 2000. Microsatellite variation in marine, freshwater and anadromous fishes compared with other animals. Journal of Fish Biology, 56: 461-473.

Estoup, A. \& J.M. Cornuet, 1999. Microsatellite evolution: inferences from population data. In: Goldstein, D.B. \& C. Schlotter, (eds.). Microsatellites: Evolution and Applications. Oxford University Press. Oxford, UK. pp 4965.

Felsenstein, J., 1985. Confidence limits on phylogenies: An approach using the bootstrap. Evolution, 39: 783-791. 
Gaggiotti, O.E., O. Lange, K. Rassmann \& C. Gliddon, 1999. A comparison of two indirect methods for estimating average levels of gene flow using microsatellite data. Molecular Ecology 8: 1513-1520.

Gardner, M.J., J.A. Chaplin, I. Potter, D.V. Fairclough \& G. Jackson, 2017. The genetic structure of a marine teleost, Chrysophrys auratus, in a large, heterogeneous marine embayment. Environmental Biology of Fishes, 100: 1411-1425.

Goldstein, D.B., A.R. Linares, L.L. Cavalli-Sforza \& M.W. Feldman, 1995. An evaluation of genetic distances for use with microsatellite loci. Genetics, 139: 463-471.

Goodman, S.J., 1997. R $\mathrm{R}_{\mathrm{ST}}$ Calc: a collection of computer programs for calculating estimates of genetic differentiation from microsatellite data and determining their significance. Molecular Ecology 6: 881-885.

Goudet J., 1995. F-STAT, a program for IBM compatible PCs to calculate Weir and Cocherham's (1984) estimates of Fstatistics. Journal of Heredity 86: 485-486.

Griffiths, M.H. \& C.G. Wilke, 2002. Long-term movement patterns of five temperate-reef fishes (Pisces: Sparidae): implications for marine reserves. Marine and Freshwater Research 53: 233-244.

Guo, S.W. \& W.A.Thompson, 1992. Performing the exact test of Hardy-Weinberg proportions using microsatellite DNA markers. Fish and Fisheries, 48: 361-372.

Hansen, M.M., E. Kenchington \& E.E. Nielsen, 2001. Assigning individual fish to populations using microsatellite DNA markers. Fish and Fisheries 2: 93-112.

Hauser, L. \& R.D. Ward, 1998. Population identification in pelagic fish: the limits of molecular markers. In: Carvalho, G. (ed.). Advances in Molecular Ecology. IOS Press, Amsterdam. pp. 191-224.

Heath, D.D., C. Busch, J. Kelly \& D.Y. Atagi., 2002. Temporal change in genetic structure and effective population size in steelhead trout (Oncorhynchus mykiss). Molecular Ecology, 11: 197-214.

Huyghe, F. \& M. Kochzius, 2018. Sea surface currents and geographic isolation shape the genetic population structure of a coral reef fish in the Indian Ocean. PLoS ONE 13(3): e0193825. 2018 doi:10.1371/journal.pone.0193825

Indab, J. \& P. Suarez-Aspilla., 2004. Community-based marine protected areas in the Bohol (Mindanao) Sea, Philippines. NAGA the ICLARM Quarterly, 27:4-8

Jarne, P. \& P.J.L. Lagoda., 1996. Microsatellites, from molecules to populations and back. Trends in Ecology and Evolution 11: 424-429.

Jones, G.P., G.R. Almany, G.R. Russ, P.F. Sale, R.S. Steneck. M.J.H. van Oppen \& B.L. Willis, 2009. Larval retention and connectivity among populations of corals and reef fishes: history, advances and challenges. Coral Reefs, 28 : 307-325.

Jorde, P.E. \& N. Ryman, 1995. Temporal allele frequency change and estimation of effective size in populations with overlapping generations. Genetics 139: 1077-1099.

Kalinowski, S.T, 2002. Evolutionary and statistical properties of three genetic distances. Molecular Ecology, 11: 1263-1273.

Kelley, J.L, A.P. Brown, N.O. Therkildsen \& A.D. Foote, 2016. The life aquatic: advances in marine vertebrate genomics. Nature Reviews Genetics, 17: 523-534.

Kimura, M. \& G.H. Weiss, 1964. The stepping-stone model of population structure and the decrease of genetic correlation with distance. Genetics, 49: 561-576.

Knutsen, H., P.E. Jorde, C. André \& N.C. Stenseth, 2003. Finescaled geographical population structuring in a highly mobile marine species: the Atlantic cod. Molecular Ecology, 12: 385-394.

Leray, M., R. Beldade, S.J. Holbrook, R.J. Schmitt, S. Planes \& G. Bernardi, 2010. Allopatric divergence and speciation in coral reef fish: the three-spot Dascyllus trimaculatus species complexes. Evolution, 64-5: 1218-1230.

Mantel, N., 1967. The detection of disease clustering and a generalized regression approach. Cancer Research, 27: 209220.

Martinez, A.S., J.R. Willoughby \& M.R. Christie, 2018. Genetic diversity in fishes is influenced by habitat type and life history variation. Ecology and Evolution, 8: 1202212031.https://doi.org/10.1002/ece3.4661

Nanninga, G., M. Mughal, P. Saenz-Agudelo, T. Beyer \& T. Berumen, 2013. Development of 35 novel microsatellite markers for the two-band anemonefish Amphiprion bicinctus. Conservation Genetics Resources, 5: 515-518.

Nei, M., 1972. Genetic distance between populations. American Naturalist, 106: 283-292.

Nei, M., 1978. Estimation of average heterozygosity and genetic distance from a small number of individuals. Genetics, 89: 583-590.

Nei, M., F. Tajima \& Y. Tateno, 1983. Accuracy of estimated phylogenetic trees from molecular data. II. Gene frequency data. Journal of Molecular Evolution, 19: 153-170.

Planes, S., 2002. Biogeography and larval dispersal inferred from population genetic analysis. In: P. Sale, (ed.), Coral Reef Fishes: Dynamics and Diversity in a Complex Ecosystem. Academic Press. San Diego, California. USA. pp. 201-220.

Raymond, M. \& F. Rousset, 1995. An exact test for population differentiation. Evolution, 49: 1280-1283.

Reiss, H., G. Hoarau, M. Dickey-Collas \& W.J. Wolff, 2009. 
Genetic population structure of marine fish: mismatch between biological and fisheries management units. Fish \& Fisheries, 10: 361-395.

Robitzch, V.S.N., D. Lozano-Cortes, N.M. Kandler, E. Salas \& M.L. Berumen, 2015. Productivity and sea surface temperature are correlated with the pelagic larval duration of damselfish in the Red Sea. Marine Pollution Bulletin, 105(2): 566-574.

Ruzzante, D.E., C.T. Taggart \& D. Cook, 1996. Spatial and temporal variation in the genetic composition of a larval cod (Gadus morhua) aggregation: cohort contribution and genetic stability. Canadian Journal of Fisheries and Aquatic Science, 53: 2695-2705.

Sanford, E. \& M.W. Kelly, 2011. Local adaptation in marine invertebrates. Annual Review of Marine Science 3: 509535.

Sukumaran, J. \& L.L. Knowles, 2017. Multispecies coalescent delimits structure, not species. Proceedings of the National Academy of Sciences of the United States of America, 114: 1607-1612.

Treml, E.A. \& P.N. Halpin, 2012. Marine population connectivity identifies ecological neighbors for conservation planning in the Coral Triangle. Conservation Letters, 5(6): 441-449.

Ward, R.D., 2002. The genetics of fish population. In: P.J.B. Hunt and J.D. Reynolds, (eds.), The Handbook of Fish and Fisheries, Fish Biology, vol. 1. Blackwell Science, Oxford. pp. 200-224.

Ward, R.D., T.S. Zemlak, B.I. Innes, P.R. Last \& P.D.N. Hebert, 2005. DNA barcoding Australia's fish species. Philosophical Transactions of the Royal Society B, Biological Sciences, 360: 1847-1857. 